\title{
The diet of high-arctic seabirds in coastal and ice-covered, pelagic areas near the Svalbard archipelago
}

\author{
F. MEHLUM and G. W. GABRIELSEN
}

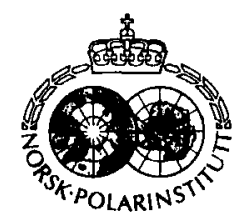

\begin{abstract}
Mehlum, F. \& Gabrielsen, G. W. 1993: The diet of high-arctic seabirds in coastal and ice-covered, pelagic areas near the Svalbard archipelago. Polar Research 12(1), 1-20.

Food samples from six high-arctic seabird species were collected during spring and summer seasons between 1982 and 1990 in the Svalbard region. The material came from coastal localities on the island of Spitsbergen and the marginal ice zone in eastern Svalbard waters. Polar cod Boreogadus saida was the most frequently occurring prey in the ice-covered areas. Analysis of otoliths showed that most polar cod were one- or twoyear olds. These year classes are known to associate with sea ice. Other ice-associated (sympagic) organisms, such as gammarid amphipods, were not found to be of high importance as prey for seabirds in the study area. However, the sea ice occurring in the area was mainly one year old. Such ice contains a less developed sympagic fauna than multi-year ice. The pelagic amphipod Parathemisto libellula, which is not sympagic but occurs in the water column, was also found to be an important prey in the marginal ice zone, especially for the Brünnich's guillemot Uria lomvia. The smallest of the seabird species studied, the little auk Alle alle, differed from the other five species in its diet, preying mainly upon smaller items such as copepods and young stages of amphipods, euphausiids and decapods. The diet of the various seabird species was in general more diverse in the coastal areas than in the marginal ice zone.
\end{abstract}

F. Mehlum and G. W. Gabrielsen*, Norwegian Polar Institute, P.O. Box 5072 Majorstua, N-0301 Oslo, Norway.

\section{Introduction}

The waters around the Svalbard archipelago support large populations of several species of seabirds (Mehlum 1989; Mehlum \& Bakken in press). These populations consume a variety of marine organisms. There is little knowledge available about the impact of the seabirds on the marine ecosystem in this part of the Arctic and the functional role of seabirds in the ecosystem as predators on marine organisms. The diets of seabirds in ice-covered, pelagic and coastal areas around the Svalbard archipelago and the northern Barents Sea have not previously been studied in detail. A general review of the available information up to 1959 is given by Løvenskiold (1964). The most comprehensive published studies of seabird diets in coastal parts of the Svalbard area are those by Hartley \& Fisher (1936) and Lydersen et al. (1989). Some preliminary results of parts of our own studies have been published elsewhere (Mehlum \& Gjertz 1984; Gjertz et al. 1985; Mehlum 1990).

Several authors have recently emphasised the importance of ice-edges and the marginal ice zone in polar seas as foraging areas for seabirds (see Hunt 1991 for review). These habitats are abun- dant in the waters near Svalbard and may be crucial for the subsistence of the seabirds in this area. In the ice-related habitats seabirds may exploit the pelagic zooplankton and fish species as well as the fauna associated with the under-ice surface (sympagic fauna), dominated by gammarid amphipods and young polar cod Boreogadus saida (Bradstreet 1980).

This paper describes the diet of seabirds in the Svalbard area during spring and summer seasons between 1982 and 1990 . We present analyses of foods found in the stomachs of six species of seabirds: northern fulmar Fulmarus glacialis, black-legged kittiwake Rissa tridactyla, ivory gull Pagophila eburnea, Brünnich's guillemot Uria lomvia, black guillemot Cepphus grylle, and little auk Alle alle. All seabird species except the ivory gull were collected both in coastal areas with no sea ice and in the marginal ice zone in the northern Barents Sea. The ivory gull was collected only in the marginal ice zone. Three of these species are surface feeders and three pursuit diving subsurface feeders. In particular, we wanted to investigate the importance of fauna associated with the sea ice subsurface to seabirds foraging in the marginal ice zone, and to compare the diets of

\footnotetext{
* Present address: Norwegian Institute for Nature Research, c/o Troms $\emptyset$ Museum, N-9000 Tromsф, Norway.
} 
birds foraging in coastal versus ice-covered, pelagic areas.

\section{Physical and biological setting}

Seabirds are present in the Svalbard region all year, both in water areas that are open and partly ice-covered, but the number of individuals in the area are highest in the summer months. Fulmars and several species of alcids and larids breed on steep cliffs along the coasts. The largest colonies are found in the northwestern, southwestern and southeastern parts of the archipelago, including the two islands, Hopen and Bjørnøya (Bear Island) (Fig. 1).

The Svalbard archipelago is located north of the shallow and productive Barents Sea. These islands, except for Bjørnøya $\left(74^{\circ} 30^{\prime} \mathrm{N}\right)$, are located between 76 to 81 degrees north latitude (Fig. 1). They experience a high-arctic climate, with maximum mean summer temperatures reaching $4-5^{\circ} \mathrm{C}$. Despite the extreme northern location, the area is one of the most easily accessible for seabirds of the High Arctic. This is primarily due to the presence of open water during

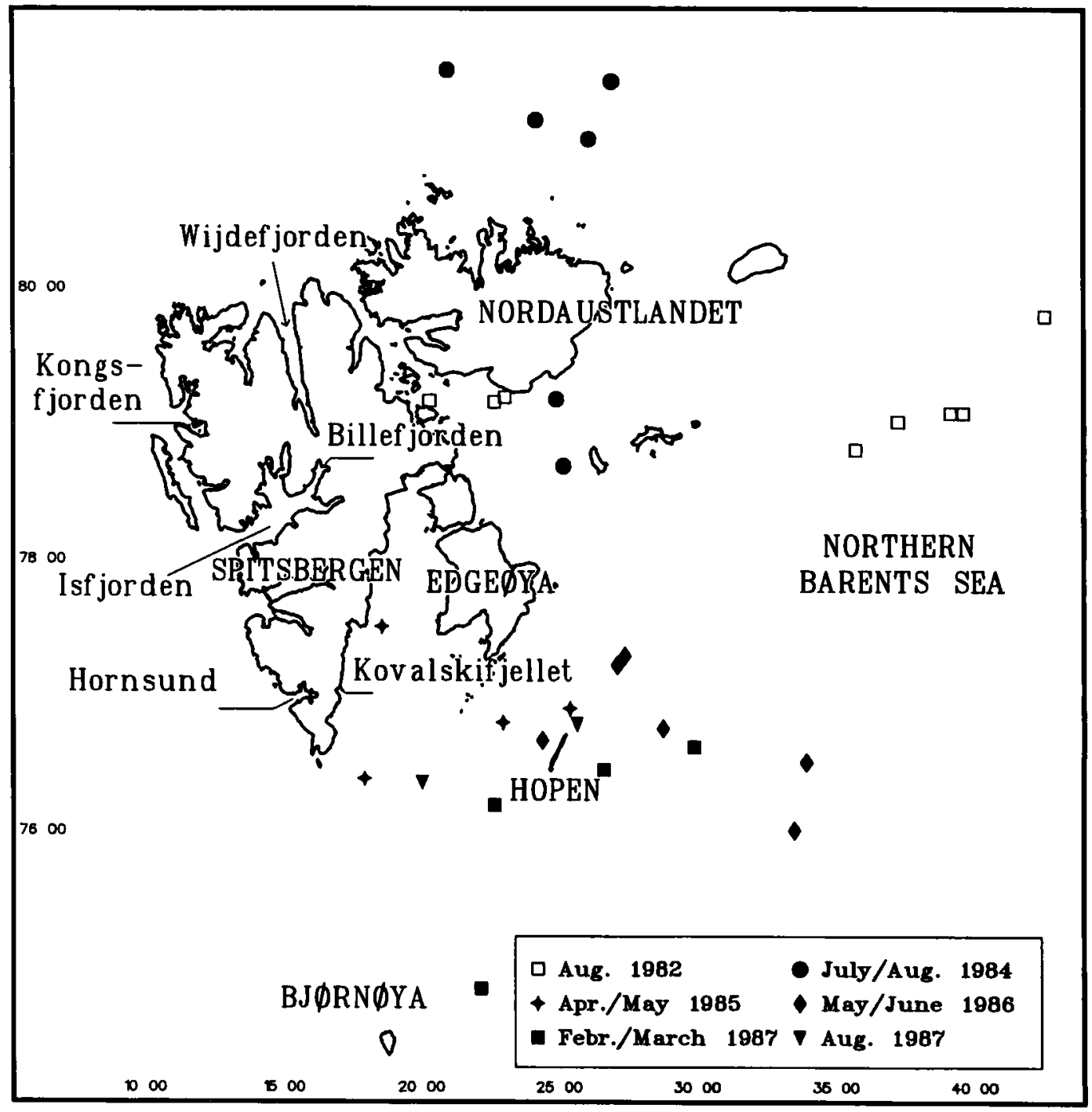

Fig. 1. Sketch map of the study area and locations of sampling, stations. 
a large part of the year, especially in the western parts of the archipelago. Throughout the year, a branch of the North Atlantic Current transports enormous masses of relatively warm water northwards into the Barents Sea and along the western coasts of Svalbard (Loeng 1989). These water masses mix with the cold polar water, and in the frontal areas a rich marine production occurs (Loeng 1989). The resultant large biomass of pelagic invertebrates and fish provides the food basis for the seabird populations inhabiting the area.

The extent of the ice cover in these waters varies from year to year and at different times of the year (Vinje 1985). Marginal ice zones are very productive areas due to high levels of inorganic nutrients and little vertical mixing of near surface water (Sakshaug \& Skjoldal 1989). The phytoplankton bloom is grazed by copepods and other zooplankters, which in turn provide food for larger organisms such as fish and seabirds. During the spring and summer seasons, the productive areas gradually recede northwards with the marginal ice zone.

\section{Materials and methods}

\section{Data collection}

The sampling periods, geographical areas and the numbers of samples obtained from each seabird species are shown in Table 1. Most seabirds were collected at sea. All specimens shot were fully grown individuals if not otherwise indicated. Actively feeding birds were preferred, but most of the specimens were collected while flying. Within 30 min after being shot, the birds were placed whole in a deep-freeze, or the stomachs and esophagus tracts were removed and either stored in a deep-freeze or preserved in $70 \%$ ethanol. Food samples from Kittiwakes at breeding colonies in the Kongsfjorden area were collected by catching adults and chicks on the nests and inducing the birds to regurgitate their food into plastic bags. Similarly, chick-feeding little auks in the Hornsund and Isfjorden areas were captured upon returning to their nests and their sublingual pouches were emptied and the contents placed in plastic bags. These samples were placed in a deepfreeze $\left(-20^{\circ} \mathrm{C}\right)$. A third method of collecting data, used in 1989 at Kovalskifjellet in Storfjorden, was direct observation of food brought by parents of young Brünnich's guillemots to the breeding ledges. The primary prey brought to the young were fish, and the different taxa could be determined in most instances (96\%).

\section{Data analyses}

For identification of prey, the stomach contents were first washed into a $0.5 \mathrm{~mm}$ sieve. All items were then sorted to the lowest possible taxon using available keys and, when possible, reference

Table 1. Sampling localities, month/year, and sample sizes of six species of seabirds. Only birds containing identifiable prey taxa are included.

\begin{tabular}{|c|c|c|c|c|c|c|}
\hline Locality/Month/year & $\begin{array}{l}\text { Fulmar } \\
n=50\end{array}$ & $\begin{array}{l}\text { Kittiwake } \\
\mathrm{n}=123\end{array}$ & $\begin{array}{l}\text { Ivory gull } \\
n=19\end{array}$ & $\begin{array}{l}\text { Brünnich's } \\
\text { guillemot } \\
n=276\end{array}$ & $\begin{array}{l}\text { Black } \\
\text { guillemot } \\
\mathbf{n}=73\end{array}$ & $\begin{array}{l}\text { Little auk } \\
\mathrm{n}=178\end{array}$ \\
\hline \multicolumn{7}{|l|}{ Marginal ice-zone } \\
\hline Svalbard E, Aug. 1982 & 14 & 13 & 6 & 1 & 7 & 21 \\
\hline Svalbard E, July/Aug. 1984 & 8 & 18 & 3 & 3 & 2 & 0 \\
\hline Svalbard E, Apr./May 1985 & 0 & 14 & 10 & 9 & 2 & 7 \\
\hline Svalbard E, May/June 1986 & $\mathbf{0}$ & 12 & 0 & 28 & 10 & 8 \\
\hline Svalbard E. Febr./March 1987 & 0 & 0 & 0 & 29 & 0 & 0 \\
\hline Svalbard E. Aug. 1987 & 0 & 0 & 0 & 9 & 0 & 0 \\
\hline \multicolumn{7}{|l|}{ Coastal areas } \\
\hline Kongsfjorden, July $1982 / 83$ & 0 & 14 & 0 & 0 & 0 & 0 \\
\hline Kongsfjorden, June 1984 & 0 & 5 & 0 & 5 & 0 & 0 \\
\hline Kongsfjorden, June/July 1985 & 0 & $\mathbf{0}$ & $\mathbf{0}$ & 7 & 23 & 14 \\
\hline Kongsfjorden, July/Aug. 1987 & 0 & 22 & 0 & 0 & 0 & 0 \\
\hline Hornsund, March/Apr. 1985 & 28 & 25 & 0 & 4 & 29 & 15 \\
\hline Hornsund, July/Aug. 1987 & 0 & 0 & 0 & 0 & 0 & 99 \\
\hline Kovalskifjellet, Storfj., Aug. 1989 & 0 & 0 & 0 & 161 & 0 & 0 \\
\hline Isfjorden, July 1990 & 0 & 0 & 0 & 0 & 0 & 14 \\
\hline
\end{tabular}


specimens. Identification of prey was primarily based on fish otoliths, squid beaks, polychaete jaws, crustacean exoskeletons and intact specimens.

All otoliths were counted and (if intact) lengths measured to the nearest $0.1 \mathrm{~mm}$ using a microscope with a measuring ocular. Two otoliths differing less than $0.2 \mathrm{~mm}$ in length were considered to be from the same fish. The number of fish ingested was estimated as half the number of otoliths within each $0.2 \mathrm{~mm}$ length category. In the samples from Hornsund in spring 1985, the number of fish ingested was based only on the total number of otoliths divided by two. The lengths of polar cod specimens were estimated according to Frost \& Lowry (1981) where fish length $(\mathrm{cm})=2.198 \mathrm{x}+1.588(\mathrm{x}$ is otolith length in $\mathrm{mm}$ ).

The sizes of polar cod found in different bird species in spring and summer were compared to the classification of age classes given by Lønne \& Gulliksen (1989). They found that the mean fork length of one-year-old specimens was $81.6 \mathrm{~mm}$ $(\mathrm{SD}=9.3)$ in the period 25 May-4 June, and $102.0 \mathrm{~mm}(\mathrm{SD}=12.6)$ in the period 31 July7 August. Two-year-old polar cod had correspondingly mean lengths of $108.7 \mathrm{~mm}(\mathrm{SD}=$ $9.1)$ and $125.3 \mathrm{~mm}(\mathrm{SD}=21.6)$. Lønne \& Gulliksen found no older age-classes associated with sea ice. Student $t$-test was used for determining differences in sizes of polar cod taken by different seabird species.

A count was made of the crustaceans in each stomach or estimated from subsamples when present in large numbers. The length of whole crustaceans was measured to the nearest $\mathrm{mm}$. When only fragments were encountered, the length of the posterior part was measured to the nearest $0.1 \mathrm{~mm}$ by means of microscope and measuring ocular (Bradstreet 1980). Estimates of total length based on the measurements of posterior parts were made in accordance with the equations given by Bradstreet (1980). For the summer samples of little auks, wet weights of crustaceans were used. Dry weights of amphipods were estimated from total lengths according to the equations given by Bradstreet (1980). Wet weights were then estimated from the dry weights. For the water content of Parathemisto libellula we used the value $82.4 \%$ given by Ikeda \& Skjoldal (1989), and for unidentified amphipods we used an estimated value of $80 \%$. The different age groups of the euphausiid Thysanoessa inermis were determined according to Dalpadado (1989), who classified first year individuals at $13-18 \mathrm{~mm}$ and second year individuals at $20-25 \mathrm{~mm}$.

In the little auk samples from Isfjorden in 1990, the total length (LT, in $\mathrm{mm}$ ) of copepods was measured from the tip of the head to the end of the furca (accuracy $0.01 \mathrm{~mm}$ ). Conversion from length to dry weight $(\mu \mathrm{g})$ of Calanus was based on the relationships given by Franz \& Diel (1984): Dry weight $=10^{(1.167179+0.360073 \mathrm{LT})}$.

A water content of $73.5 \%$, which was given for Calanus finmarchicus adult females (Ikeda \& Skjoldal 1989), was used for estimating wet weight from dry weight of $C$. finmarchicus/glacialis.

The number of polychaetes ingested was determined by counting the number of polychaete jaws present in the stomach sample. Similarly, squid were identified by their beaks. When both upper and lower halves of beaks were present in the stomach sample, the number of squid ingested was determined by counting the lower beaks of squid present.

In order to reduce the number of prey categories, the food items recorded were grouped into the following taxa: nereids (Polychaeta, Nereidae), gastropods, cephalopods, copepods, gammarids (Gammaridea), hyperiids (Hyperiidea), Amphipoda indet., euphausiids, decapods, polar cod, other fishes, Pisces indet., and others.

Remains of crustaceans which could not be identified to a lower taxonomic level than Amphipoda were classified under "Amphipoda indet.". Similarly polar cod is treated separately from other fishes because of its importance in seabird diets. "Other fishes" includes all identifiable fishes except for polar cod. "Pisces indet." comprises fish remains not identified, which may also include polar cod remains.

We mainly used the frequency of occurrence and the numerical abundance of different prey taxa in the analysis of the diet of the different seabird species (Duffy \& Jackson 1986). Frequency of occurrence was determined for each bird species as the percentage of sampled birds in which the prey type occurred (empty stomachs were not included). Numerical abundance was defined as the percentage in numbers of a prey type compared to the total number of identified prey items. Percentage by weight was calculated by dividing the weight of a particular prey type by the total weight of all prey combined. The latter measure was applied for the little auk samples, only. 
In comparing similarity in diets we used Morisita's index, "C", of overlap (Horn 1966; Diamond 1983) on our frequency of occurrence data. This index ranges from 0 (no overlap) to 1 (complete overlap). This index is usually applied to numerical abundance data. We chose rather to use frequency of occurrence because in many of our samples good values of numerical abundance of some taxa could not be obtained due to decay of the food items in the stomachs of the birds. We believe that this use of the index is suitable for determining which species are most similar in diet. Cluster analyses using the single linkage method (Pielou 1984) were made, and tree diagrams were constructed, based upon indices of dissimilarity, " $D "=1-C$.

\section{Difficulties in data interpretation}

In the analysis of seabird stomach samples, single measures of diet carry bias and have the potential to distort the true diets of the birds. For example, often only fragments of prey items are found, mainly the least digestible parts such as fish otolithis, squid beaks, and polychaete jaws. Thus, although the frequency of occurrence measurement is easily obtainable, it will over-represent the most persistent prey species found in the stomach samples as well as prey which are only present in low numbers. If the sample contains considerable differences in prey sizes, the numerical abundance measure of diet tends to overestimate the importance of small prey. Adequate measurement of a seabird's diet would be the mass or the nutritional value of freshly ingested matter of the different prey taxa. However, such information is usually not available because of the different states of digestion of the prey items. For some prey species it is possible, on the basis of allometrical relationships, to estimate the total length or mass of specimens from the lengths of different body parts. These problems have been discussed in detail by Duffy \& Jackson (1986).

Such diet measurement problems do not apply to seabird species which carry food to their young in their beaks or gular pouches. In our study, only little auks feeding their young give suitable data on prey composition by mass.

This study is based on material collected over several years. In the Results section we have combined data from the various years, and our interpretation of the diets of the different seabird species may be biased by inter-annual variation in food availability. We have combined the data because of low sample sizes in individual sampling periods. The samples collected in ice-covered areas were collected over a wider geographical area in the marginal sea ice zone in eastern parts of Svalbard rather than at a fixed geographical locality. In addition, spring samples were obtained in areas farther south than the summer samples because of seasonal differences in icecover.

\section{Results}

Diet composition of seabird species in coastal areas versus the marginal ice zone

Fulmar Fulmarus glacialis. - The diet of 50 birds included nereids, cephalopods, crustaceans and fish (Fig. 2). Nereids (Nereis irrorata), cephalopods (Gonatus fabricii) and polar cod occurred most frequently in the pelagic samples, while cephalopods, decapods and fish other than polar cod dominated the coastal samples. The pelagic amphipod Parathemisto libellula occurred only in samples from the marginal ice zone, $22.7 \%$ of those examined. Nereids occurred in $45.5 \%$ of fulmar samples from the marginal ice zone, and none were found in samples from coastal areas. Cephalopods occurred in $31.8 \%$ and $75.0 \%$ of the birds from ice-covered and coastal areas, respectively.

Kittiwake Rissa tridactyla. - Polar cod was the dominant food taxon in the marginal ice zone ( $70.2 \%$ of the birds), but lower $(28.8 \%)$ in coastal areas (Table 2). In the total material, polar cod was found in $48.0 \%$ of the birds. The pelagic amphipod Parathemisto, occurred in $30.3 \%$ of the bird specimens from coastal areas, but was not found in birds from the marginal ice zone. Other taxa present in the coastal samples were cephalopods, copepods and euphausiids.

In the coastal spring samples (Hornsund in March/April 1985), polar cod occurred in $44.0 \%$ of the birds along with other fish including lantern fish Benthosema sp., Atlantic cod Gadus morhua, and snailfish Liparidae (Fig. 3). Other prey of Hornsund birds were squid (Gonatus fabricii) and polychaetes (Nereis irrorata), with smaller numbers of amphipods and decapods.

During chick-rearing, euphausiids and amphipods were more frequent in the birds sampled in 
Table 2. Frequency of occurrence of prey taxa (\% of birds investigated) in kittiwakes Rissa tridactyla, Brünnich's guillemots Uria lomvia, black guillemots Cepphus grylle, and little auks Alle alle, in birds collected in the marginal ice zone (MIZ) versus coastal areas (C). Chick diet of Brünnich's guillemots from Kovalskifjellet is shown separately (K). Sample sizes in brackets.

\begin{tabular}{|c|c|c|c|c|c|c|c|c|c|}
\hline \multirow[b]{2}{*}{$\begin{array}{l}\text { Prey } \\
\text { taxon }\end{array}$} & \multicolumn{2}{|c|}{ Kittiwake } & \multicolumn{3}{|c|}{ Br. guillemot } & \multicolumn{2}{|c|}{ Bl. guillemot } & \multicolumn{2}{|c|}{ Little auk } \\
\hline & $\begin{array}{l}\text { MIZ } \\
\text { (57) }\end{array}$ & $\begin{array}{l}C \\
(66)\end{array}$ & $\begin{array}{l}\text { MIZ } \\
\text { (89) }\end{array}$ & $\begin{array}{l}C \\
(26)\end{array}$ & $\begin{array}{l}K \\
(161)\end{array}$ & $\begin{array}{l}\text { MIZ } \\
\text { (21) }\end{array}$ & $\begin{array}{l}C \\
(52)\end{array}$ & $\begin{array}{l}\text { MIZ } \\
\text { (36) }\end{array}$ & $\begin{array}{l}C \\
(142)\end{array}$ \\
\hline Nereids & 12.3 & 16.7 & 1.1 & 11.5 & 0 & 0 & 53.8 & 0 & 0 \\
\hline Gastropods & 1.8 & 1.5 & 0 & 3.8 & 0 & 0 & 17.3 & 0 & 0.7 \\
\hline Cephalopods & 0 & 6.1 & 0 & 11.5 & 0.5 & $\mathbf{0}$ & 0 & 0 & 0 \\
\hline Copepods & 0 & 3.0 & 4.5 & 0 & 0 & 4.8 & 3.8 & 66.7 & 88.7 \\
\hline Amphipoda indet. & 1.8 & 4.6 & 22.5 & 15.4 & 0 & 0 & 21.1 & 8.3 & 4.2 \\
\hline Gammarids & 0 & 1.5 & 4.5 & 38.5 & 0 & 9.5 & 30.8 & 16.7 & 24.6 \\
\hline Hyperiids & 0 & 30.3 & 64.0 & 3.8 & 0 & 0 & 3.8 & 30.6 & 68.3 \\
\hline Euphausiids & 0 & 15.2 & 7.9 & 38.5 & 0 & 0 & 3.8 & 0 & 23.9 \\
\hline Decapods & 7.0 & 6.1 & 14.6 & 7.7 & 0 & 0 & 32.7 & 0 & 63.4 \\
\hline Polar cod & 70.2 & 28.8 & 28.1 & 34.6 & 83.9 & 71.4 & 9.6 & 5.6 & 0 \\
\hline Other fishes & 22.8 & 18.2 & 1.1 & 19.2 & 11.5 & 14.3 & 15.4 & 0 & 0 \\
\hline Pisces indet. & 24.6 & 30.3 & 14.6 & 19.2 & 4.0 & 28.6 & 21.2 & 13.9 & 18.3 \\
\hline Other & 1.8 & 1.5 & 0 & 0 & 0 & 0 & 5.8 & 19.5 & 3.5 \\
\hline
\end{tabular}

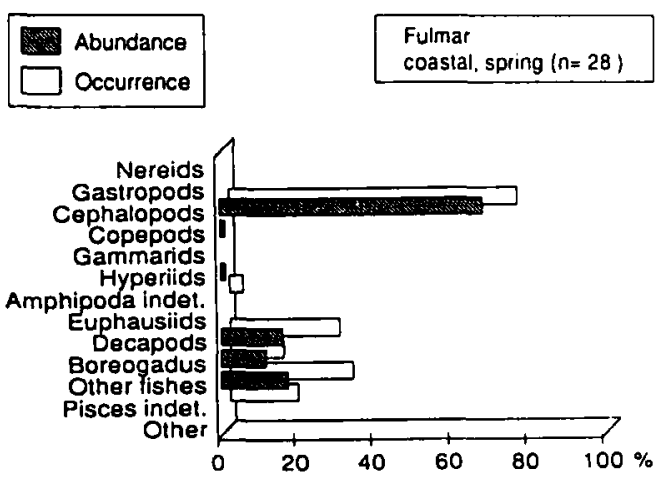

Fulmar pelagic, summer $(n=22)$

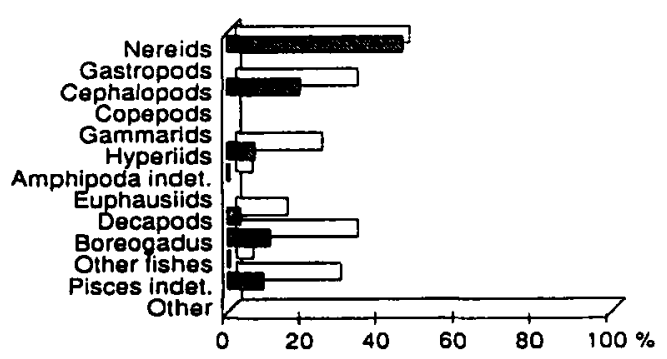

Fig. 2. Frequency of occurrence and numerical abundance (hatched) of prey taxa found in fulmars Fulmarus glacialis. coastal areas than in spring (Fig. 3). In the July/ August 1987 samples from the Kongsfjorden area, the pelagic amphipod Parathemisto libellula occurred most frequently (46.3\%), while euphausiids (mainly Thysanoessa inermis), polar cod and polychaetes (Nereis sp.) were found in $24.4 \%$, $19.5 \%$ and $19.5 \%$ of the samples, respectively.

In the marginal ice zone (Fig. 3), birds were sampled in the spring (April 1985 and May/June 1986) and summer (August 1982 and July/August 1984). Fish dominated the diet during both periods with polar cod, the species most frequently encountered during spring (frequency of occurrence $42.3 \%$ ), supplemented by coalfish Pollachius virens, haddock Melanogrammus aeglefinus, lantern fish Benthosema sp., capelin Mallotus villosus, snailfish (Liparis sp., Careproctus sp.), and blennies (Lumpenidae, Zoarcidae). The polychaete Nereis sp. was found in $23.1 \%$ of the birds. In July/August 1984 polar cod was found in $93.5 \%$ of the birds; other fish species occurred in $22.6 \%$ of the birds.

Ivory Gull Pagophila eburnea. - A total of 19 specimens of ivory gull were collected during three different periods (Fig. 4), all in pelagic areas within the marginal ice zone. Fish was the dominant prey found, and polar cod occurred in $52.6 \%$ of the birds examined. Other fish species 

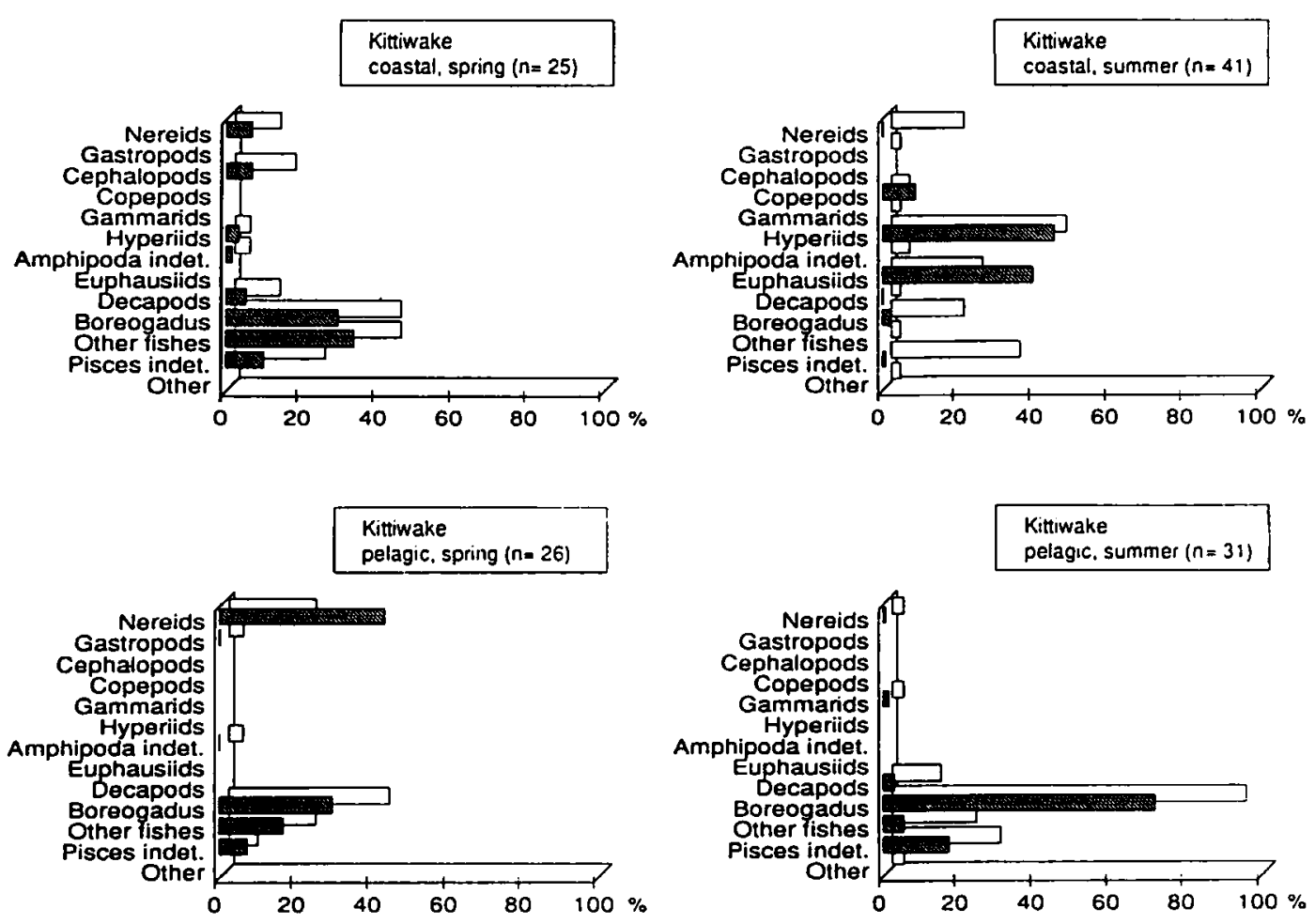

Fig. 3. Frequency of occurrence and numerical abundance (hatched) of prey taxa found in kittiwakes Rissa tridactyla.

(blenny Lycodes sp., Atlantic cod, and coalfish) occurred in $26.3 \%$ of the stomach samples, while mammal fat (probably seal) was found in $21.1 \%$ of birds. Six Gammarus wilkitzkii, a sympagic amphipod, were found in one bird. Echinoderms occurred in two birds, but was suspected of being obtained by scavenging from seal excrement.

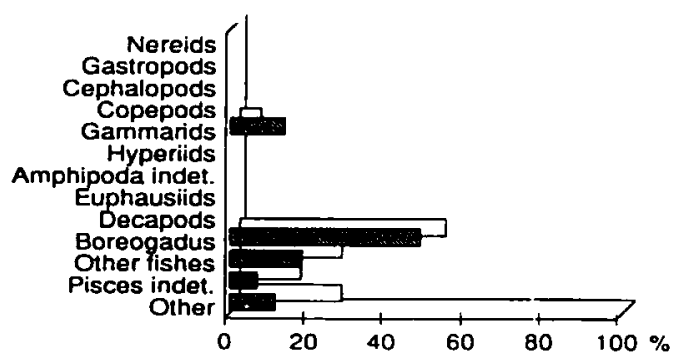

Fig. 4. Frequency of occurrence and numerical abundance (hatched) of prey taxa found in ivory gulls Pagophila eburnea.
Brünnich's Guillemot Uria lomvia. - The pelagic amphipod Parathemisto occurred in the highest frequency $(64.0 \%)$ among samples from the marginal ice zone, while gammarid amphipods and euphasiids had the highest occurrence $(38.5 \%)$ in coastal samples (Table 2). Gammarid amphipods and euphausiids were encountered in lower occurrence in the marginal ice zone $(4.5 \%$ and $7.9 \%)$. Polar cod was found in $28.1 \%$ and $34.6 \%$ of the birds in ice-covered and coastal areas, respectively.

Amphipods and euphausiids were encountered most frequently in the early spring samples from Hornsund (April/May 1985), occurring in $71.4 \%$ and $64.3 \%$ of the 14 birds, respectively. However, euphausiids (mainly Thysanoessa inermis) dominated in numbers and accounted for $68.5 \%$ of all identifiable prey items (Fig. 5). The pelagic amphipod Parathemisto was not encountered, and the dominant amphipods in the samples were Gammarellus homari and Anonyx nugax, both benthic living species. Polar cod was also a common prey, occurring in $42.9 \%$ of the birds. In the 12 summer samples from coastal areas from 

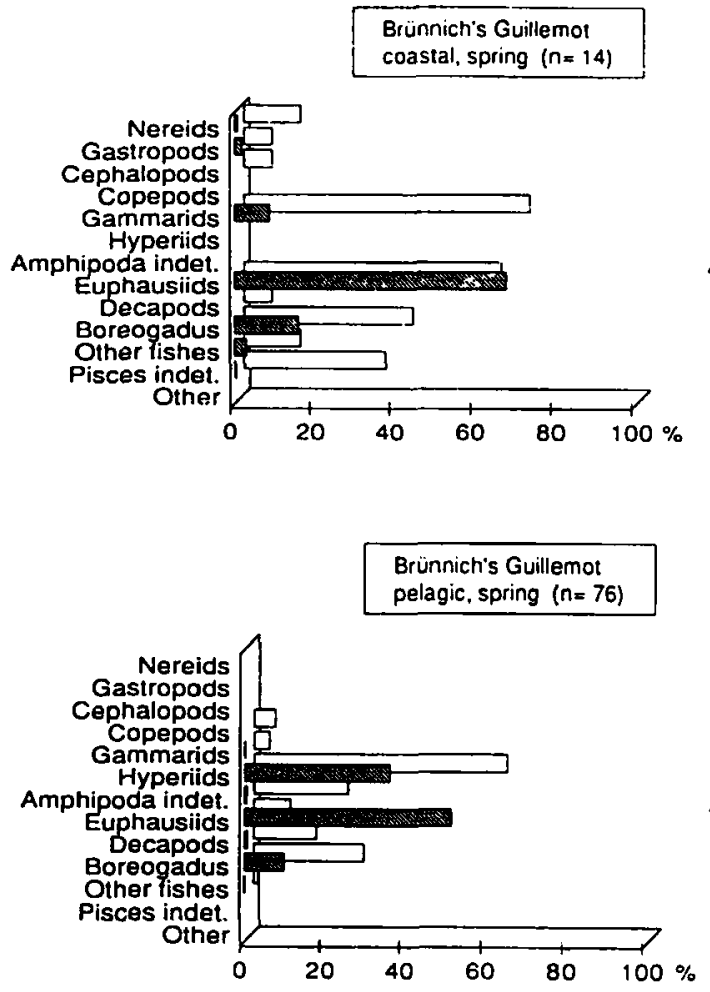

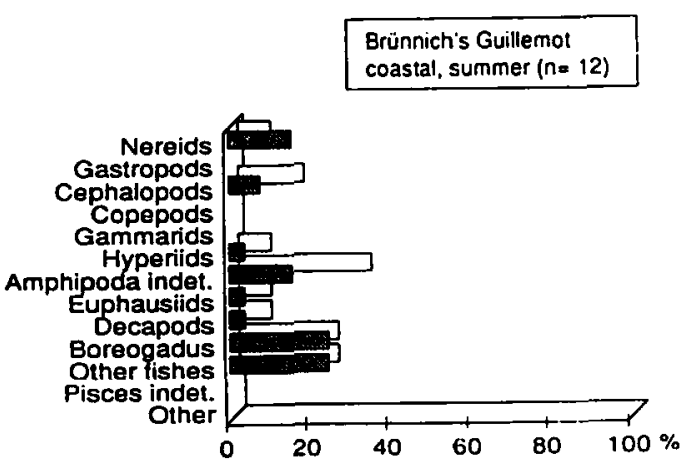

Brünnich's Guillemo pelagic, summer $(n=13)$

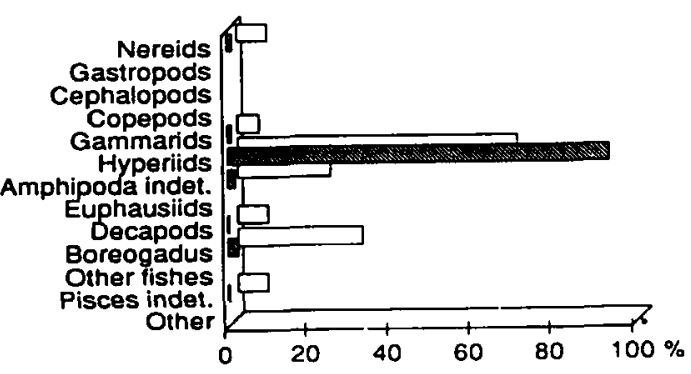

Fig. 5. Frequency of occurrence and numerical abundance (hatched) of prey taxa found in Brünnich's guillemots Uria lomvia.

Kongsfjorden (June/July 1984-85), benthic amphipods occurred most frequently (33.3\%), while polar cod and other fish species (mainly blennies and capelin) occurred in $25.0 \%$ of the birds.

The samples from the marginal ice zone during the spring period (Fig. 5) comprise a total of 76 birds from Feb./March 1987, April 1985 and late May/early June 1986. The most frequently occurring taxon was the amphipod Parathemisto, occurring in $63.2 \%$ of the samples, while polar cod occurred in $27.6 \%$ of the birds. The euphausiid Thysanoessa inermis and the amphipod Parathemisto libellula accounted for $51.3 \%$ and $36.6 \%$ of the 1486 identifiable prey items. In all but one bird the euphausiids were confined to the samples from Feb./March 1987. Decapods were encountered in $15.8 \%$ of the birds. In the April/May 1985 sample, however, the decapod Pandalus borealis was the most frequent prey: $45.6 \%$ of the stomachs.

The samples collected in ice-covered waters during the summer seasons (Fig. 5) comprise 13 birds, of which 7 were first-year birds still accompanied by one of their parents. Parathemisto was the dominant prey in the sample occurring in $69.2 \%$ of the birds and accounting for 200 of the 213 identified items (93.9\%). Polar cod was the second most important and occurred in $30.8 \%$ of the birds. Only one prey specimen of gammarid amphipods was found, the sympagic species Gammarus wilkitzkii. No difference was found between the diet of adult and first-yearbirds. Parathemisto occurred in four out of seven first-year birds (57\%).

Brünnich's guillemot chick diet was studied at Kovalskifjellet in 1989 (Table 2). In the 161 food deliveries observed the chicks were almost exclusively fed fish, of which $83.9 \%$ were polar cod, 9.9\% snakeblennies (Lumpenidae), $1.5 \%$ sculpins (Cottidae), and $4.3 \%$ unidentified fishes; one chick meal delivered was a squid.

Black Guillemot Cepphus grylle. - The diet of 
black guillemots was generally more diverse in coastal areas than in the marginal ice zone (Table 2). Benthic dwelling prey were frequent in the coastal samples, whereas polar cod was dominant in pelagic, ice-covered areas.

In inshore waters at Hornsund (March-April 1985) and Kongsfjorden (July-Aug. 1985), the diversity of prey was high with a high proportion of benthic invertebrates in addition to polar cod and benthic sculpins (Fig. 6). The polychaete Nereis irrorata had the highest frequency of occurrence $(53.8 \%$ ), followed by benthic amphipods (48.3\%) and decapods (32.7\%). In Hornsund birds polychaetes were dominant: frequency of occurrence $=96.6 \%$, and numbers $=87.3 \%$. Amphipods were also numerous, mainly $\mathrm{Gam}$ marellus homari, a species usually found in shallow water in the Hornsund region (Opalinski \& Weslawski 1989).

In offshore, ice-covered areas (Fig. 6), polar cod was the dominant prey, occurring in $71.4 \%$ of the birds, with other fishes (coalfish and Lycodes) and sympagic amphipods occurring in only $14.3 \%$
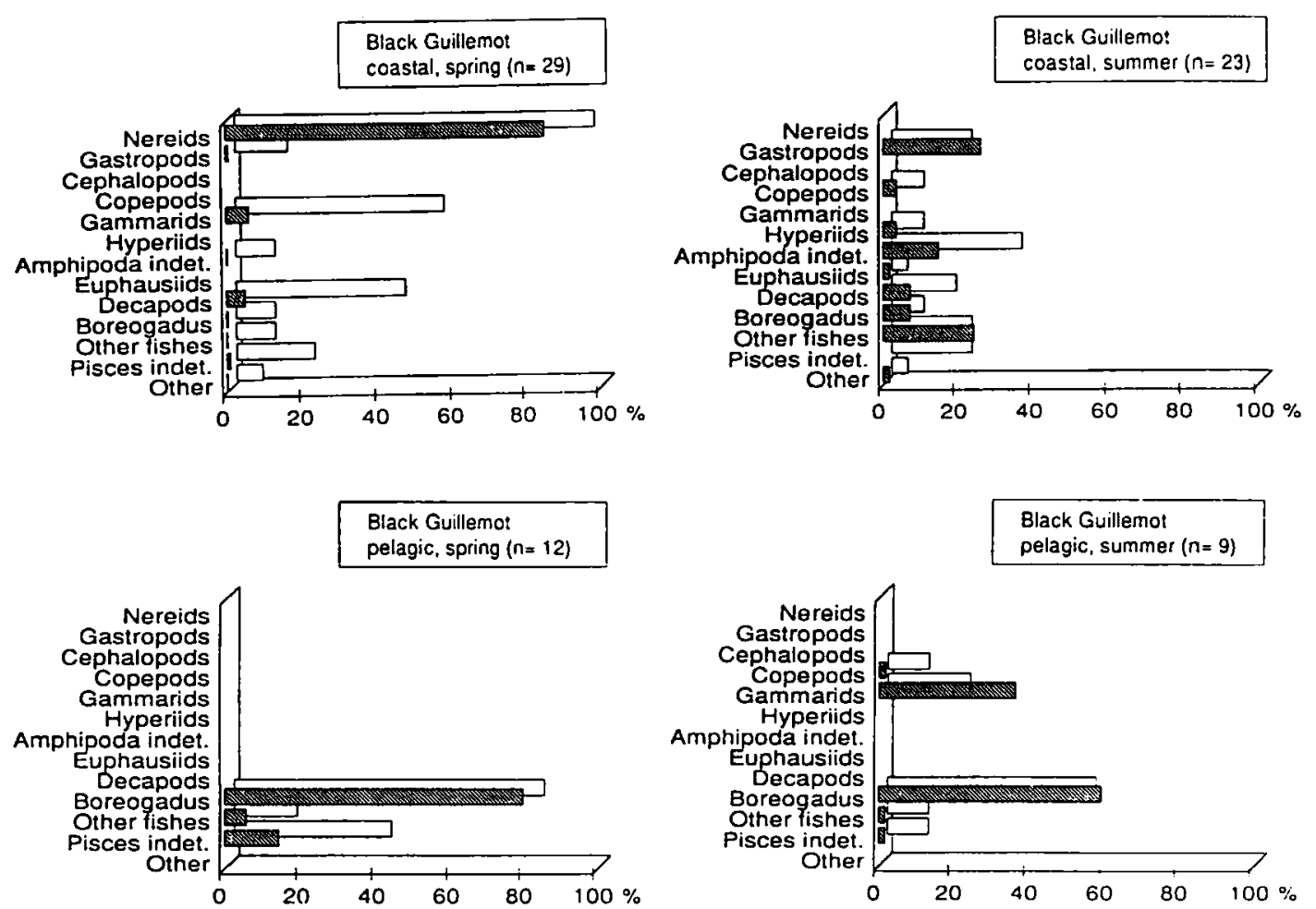

and $9.5 \%$ of the birds, respectively. Polychaetes, gastropods, Parathemisto, euphausiids, mysiids and decapods were only encountered in the coastal samples.

Little Auk Alle alle. - Little auk foods were mainly small invertebrates, with copepods dominant by occurrence and numbers. The diet in coastal waters was more diverse than in the marginal ice zone (Table 2) comprising gastropods, copepods, amphipods, euphausiids, decapods, chaetognaths and fish larvae. Gastropods, euphausiids and decapods were not present in the pelagic samples. The only coastal area spring sample is from Hornsund in March/April 1985. Copepods were found in $66.7 \%$ of the birds. However, amphipods other than Parathemisto and euphausiids were also frequent in the diet, and the latter accounted for $92.4 \%$ of the number of prey items recorded except for copepods.

Copepods were present in $91.3 \%$ of all coastal samples in summer and they accounted for $85.3 \%$ in the wet weight of the prey (Fig. 7). The pelagic

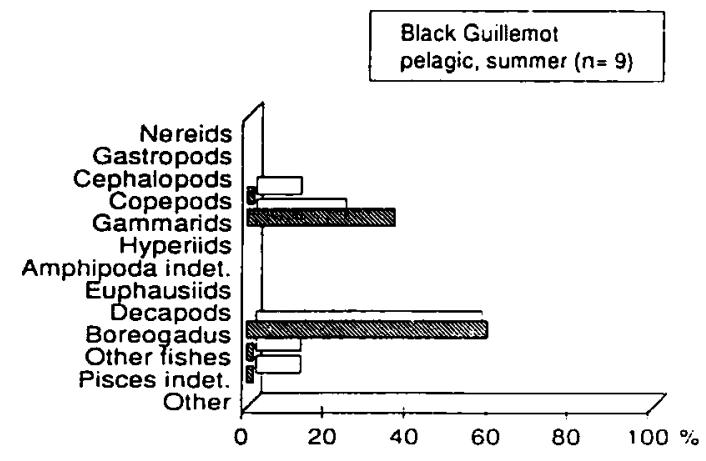

Fig. 6. Frequency of occurrence and numerical abundance (hatched) of prey taxa found in black guillemots Cepphus grylle. 

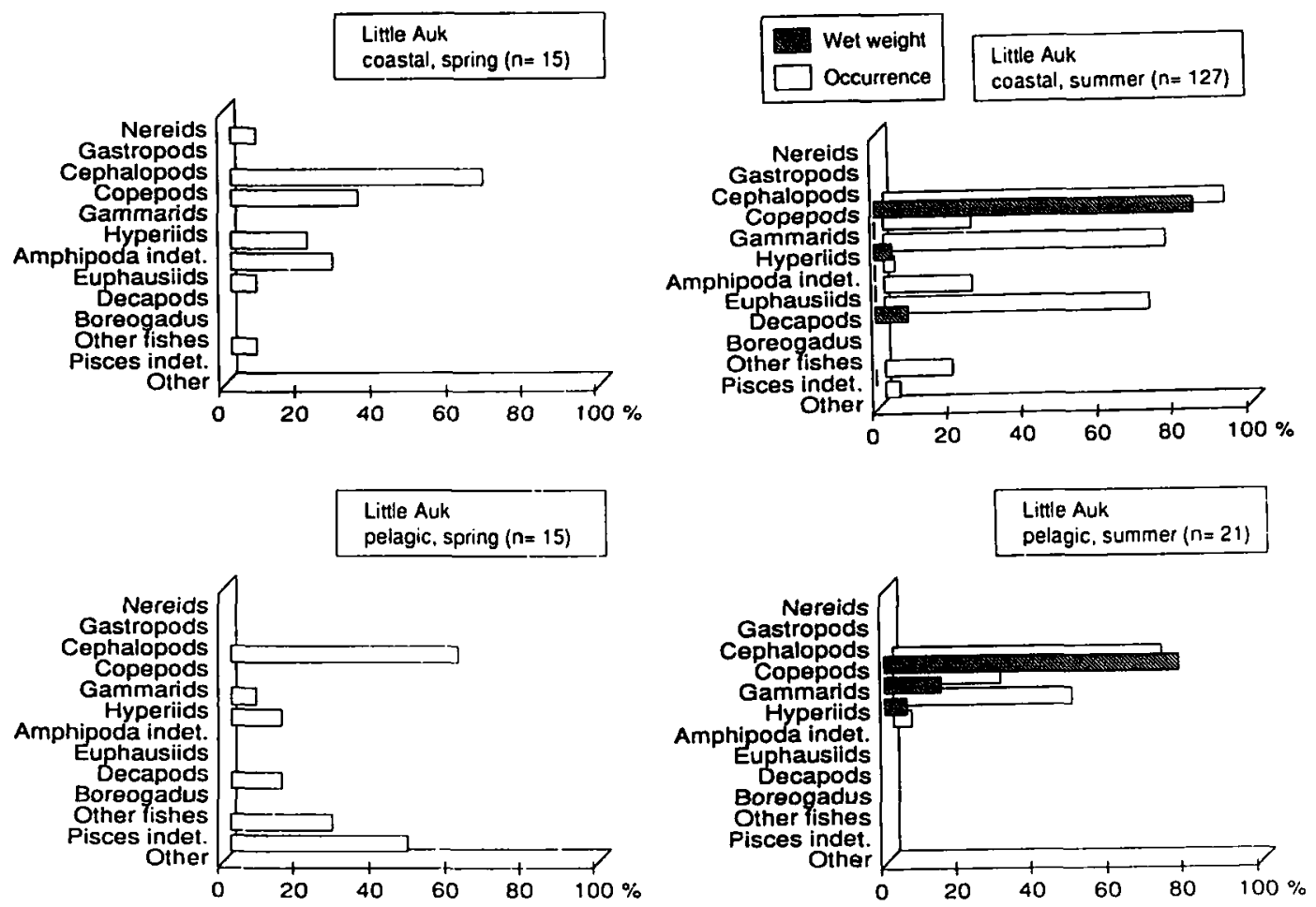

Fig. 7. Frequency of occurrence and numerical abundance (hatched) of prey taxa found in little auks Alle alle. For the coastal summer samples wet weight is presented instead of numerical abundance.

amphipods Parathemisto spp. and decapod larvae were the second and third most frequent prey items encountered, and were found in $75.6 \%$ and $70.9 \%$ of the birds, respectively. Copepods were found in all birds collected during summer in Hornsund (1987) and Isfjorden (1990), while they occurred only in $21.4 \%$ of the birds in Kongsfjorden (1985). In the Kongsfjorden sample Parathemisto was the dominant prey, occurring in $57.1 \%$ of the birds, and followed by gammarids with $28.6 \%$. The July-Aug. Hornsund birds contained $86.1 \%$ wet weight copepods, while larval stages of decapods (mainly Eupagurus) comprised the second most important prey taxon with $70.1 \%$ of the macroplankton wet weight (with copepods excluded). Parathemisto spp. constituted 25.3\% of the macroplankton wet weight and were the most important taxon relative to frequency in numbers; they accounted for $52.5 \%$ of the macroplanktonic prey items. Two species of Para-themisto were encountered. $P$. abyssorum occurred more frequently than $P$. libellula $(40.0 \%$ and $12.1 \%$ of macroplanktonic prey items, respect- ively) and contributed more to the total weight of macroplankton consumed by the birds ( $15.4 \%$ vs. $9.9 \%$ ). Euphausiids were of minor importance in the Hornsund sample and accounted for only $1.0 \%$ of the macroplankton weight. Copepods accounted for $70.9 \%$ of the total wet weight of the prey in the Isfjorden sample, while Parathemisto spp. were second $(18.5 \%)$, followed by $T h y$ sanoessa sp. (6.4\%) and decapod larvae (3.9\%). Parathemisto abyssorum was the dominant Parathemisto species (198 of 206 individuals, or $96 \%$ ).

The summer 1990 material from Isfjorden was analysed in order to describe the composition of different Calanus stages and species, and to determine their weights. Of 4903 whole specimens of copepods, C. finmarchicus/glacialis dominated with $96.0 \%$ copepodite stage $\mathrm{V}$ (mean dry weight per individual copepod $408 \mu \mathrm{g}$ ), $1.9 \%$ females stage VI (mean dry weight $839 \mu \mathrm{g}$ ), and $1.8 \%$ copepodite IV (mean dry weight $187 \mu \mathrm{g}$ ). Only five specimens of $C$. hyperboreus were found, three of copepodite IV (mean dry weight $685 \mu \mathrm{g}$ ) and two copepodite $V$ (mean dry weight $2267 \mu \mathrm{g}$ ). 
The estimated dry weights of $C$. finmarchicus/ glacialis from the pelagic samples of summer 1982 averaged $608 \mu \mathrm{g}$ (range: $192-928 \mu \mathrm{g}, \mathrm{n}=20$ ).

In the spring samples from the marginal ice zone, copepods and chaetognaths were most frequently encountered and occurred in $60.0 \%$ and $46.7 \%$ of the birds, respectively (Fig. 7, chaetognaths are listed as "others"). The pelagic amphipod Parathemisto libellula, sympagic amphipods, and one-year old individuals of polar cod were found in much lower percentages of the birds. Late summer samples from pelagic, ice-covered areas (Fig. 7) contained only copepods, Parathemisto libellula and sympagic, gammarid amphipods (mainly Apherusa glacialis and Gammarus wilkitzkii). Estimates of dry weights of the different prey taxa showed that gammarid amphipods, which were found in $28.6 \%$ of the birds, accounted for as much as $78.9 \%$ of the total weight of the prey.

\section{Comparison of diet between seabird species and habitats}

A matrix of the frequency of occurrence of different prey taxa in the six seabird species investigated are shown in Table 3 where they are separated by habitat: ice-covered versus coastal areas. Polar cold was important for all seabird species (except the little auk) in the pelagic, partly ice-covered areas, but less important in the coastal samples where all bird species had a more varied diet.

A second important prey taxon in the marginal ice zone was hyperiid amphipods. Parathemisto libellula was the most common hyperiid in Brünnich's guillemots, and also frequent in fulmars and little auks in the marginal ice zone, and in kittiwakes from coastal areas. On the other hand, $P$. abyssorum was dominant in little auks from coastal areas. Nereids were frequent in fulmars and kittiwakes in offshore areas, and in kittiwakes, Brünnich's guillemots and black guillemots in coastal waters. Cephalopods occurred in three seabird species, but the frequency of occurrence was $>10 \%$ in only two species. They were encountered in very high frequency in fulmars in coastal areas, and less frequent in Brünnich's guillemots and kittiwakes. In the marginal ice zone they were found only in fulmars, but at a lower level than along the coast.

Certain prey taxa had a frequency of occurrence of larger than $10 \%$ in only a single seabird species: copepods and chaetognaths in little auks, gastropods in coastal black guillemots, and mammal fat in ivory gulls.

Table 3. Summary table of the frequency of occurrence of different prey taxa in seabirds sampled in the marginal ice zone and coastal areas.

\begin{tabular}{|c|c|c|c|c|c|c|c|c|c|c|c|c|c|}
\hline $\begin{array}{l}\text { Frequency of } \\
\text { occurrence } \\
\text { in bird stomachs } \\
X=10-40 \% \\
X X=40-70 \% \\
X X X>70 \% \\
\end{array}$ & 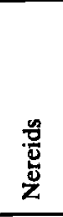 & 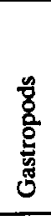 & 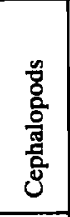 & 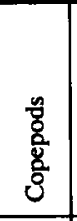 & 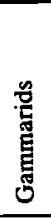 & 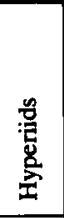 & 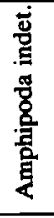 & 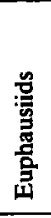 & 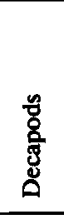 & 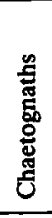 & $\begin{array}{l}z \\
8 \\
\vdots \\
0 \\
0\end{array}$ & 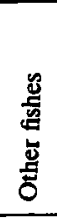 & 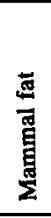 \\
\hline $\begin{array}{l}\text { MARGINAL ICE ZONE } \\
\text { Fulmar } \\
\text { Kittiwake } \\
\text { Ivory gull } \\
\text { Brünnich's guillemot } \\
\text { Black guillemot } \\
\text { Little auk } \\
\end{array}$ & $\underset{\mathbf{X}}{\mathbf{X X}}$ & & $x$ & $\mathbf{X X}$ & $\mathrm{x}$ & $\begin{array}{l}\mathrm{X} \\
\mathrm{xx} \\
\mathrm{x}\end{array}$ & $x$ & & $\begin{array}{l}x \\
x\end{array}$ & $\mathrm{X}$ & $\begin{array}{c}\mathbf{X} \\
\mathbf{X X} \\
\mathbf{X X} \\
\mathbf{X} \\
\mathbf{X X X}\end{array}$ & $\begin{array}{l}X \\
X \\
X\end{array}$ & $x$ \\
\hline $\begin{array}{l}\text { COASTAL AREAS } \\
\text { Fulmar } \\
\text { Kittiwake } \\
\text { Brünnich's guillemot } \\
\text { Black guillemot } \\
\text { Little auk } \\
\end{array}$ & $\underset{\mathbf{x}}{\mathbf{x}}$ & $\mathbf{X}$ & $\begin{array}{c}\mathbf{X x X} \\
\mathbf{x}\end{array}$ & $\mathbf{x x x}$ & $\begin{array}{l}X \\
\mathbf{X} \\
\mathbf{X}\end{array}$ & $\begin{array}{c}\mathbf{X} \\
\mathbf{x x} \\
\end{array}$ & $\begin{array}{l}\mathbf{X} \\
\mathbf{X}\end{array}$ & $\begin{array}{l}\mathbf{X} \\
\mathbf{X} \\
\mathbf{X} \\
\end{array}$ & $\begin{array}{c}\mathbf{X} \\
\mathbf{X} \\
\mathbf{X X} \\
\end{array}$ & & $\begin{array}{l}x \\
x \\
x\end{array}$ & $\begin{array}{l}\mathbf{X} \\
\mathbf{X} \\
\mathbf{X}\end{array}$ & \\
\hline
\end{tabular}


Table 4. Morisita's indices for dietary overlap between seabirds sampled in the marginal ice zone and coastal areas in the Svalbard region. The indices are based on frequencies of occurrence.

MARGINAL ICE ZONE

\begin{tabular}{llllll}
\hline Species & FUGLA & RITRI & PAEBU & URLOM & CEGRY \\
\hline Fulmar & 0 & & & & \\
Kittiwake & 0.62 & 0 & & & \\
Jvory gull & 0.46 & 0.90 & 0 & 0 & 0 \\
Brünnich's guillemot & 0.54 & 0.41 & 0.37 & 0.41 & 0.20 \\
Black guillemot & 0.53 & 0.97 & 0.88 & 0.47 & 0.11 \\
Little auk & 0.22 & 0.12 & & & \\
\hline
\end{tabular}

COASTAL AREAS

\begin{tabular}{lllll}
\hline Species & FUGLA & RITRI & URLOM & CEGRY \\
\hline Fulmar & 0 & & & \\
Kittiwake & 0.38 & 0 & & \\
Brünnich's guillemot & 0.38 & 0.68 & 0 & 0 \\
Black guillemot & 0.28 & 0.53 & 0.61 & 0.33 \\
Little auk & 0.17 & 0.34 & 0.26 & \\
\hline
\end{tabular}

(FUGLA = Fulmar, RITRI = Kittiwake, PAEBU = Ivory gull, URLOM = Brünnich's guillemot, CEGRY = Black guillemot, ALALL = Little auk).

The Morisita's indices of dietary overlap between the six seabird species studied in the marginal ice zone and five species in coastal regions are shown in Table 4. These matrices are calculated from the frequencies of occurrence of each of the 14 prey categories listed in Table 3. The corresponding dendrograms of dissimilarity (Fig. 8) show that in the marginal ice zone there is a high similarity in diet between black guillemots and kittiwakes, both of which exploit iceassociated prey. Ivory gulls also showed a diet similar to these two species, while the most distant species in diet similarity was the little auk, which mainly fed upon copepods. The dendrograms indicate a lower similarity in diet between the species in coastal areas than in offshore areas. In coastal birds the highest similarity in diet was between Brünnich's guillemots and kittiwakes; both fulmars and little auks had very low dietary overlap indices in coastal regions.

The highest dietary overlap between marginal ice zone and coastal habitats by applying Morista's index was for little auks $(0.72)$, followed by kittiwakes $(0.70)$, and fulmars $(0.57)$. The lowest overlap value was for the black guillemot (0.29), probably reflecting its benthic versus under-ice foraging habits. The value for Brünnich's guillemot was intermediate $(0.43)$.

Sizes of polar cod, Parathemisto spp. and Thysanoessa inermis consumed by seabirds

A comparison of prey sizes for different seabird species and seasons allows the predominant prey cohorts and differences between predator species to be determined. Length distributions of polar cod based on otolith lengths (Fig. 9) and Lønne \& Gulliksen's (1989) classification indicate that in spring Brünnich's guillemots and little auks feed mainly on one-year-old cod. The mean lengths of polar cod in the Brünnich's guillemots collected during spring varied from 75 to $96 \mathrm{~mm}$ between samples, whereas those from the single sample set of little auks averaged $81 \mathrm{~mm}$. The polar cod taken by kittiwakes and black guillemots comprised individuals of both one-year-old and older. Mean lengths in spring varied from 78 to $115 \mathrm{~mm}$ for black guillemots, and from 83 to $131 \mathrm{~mm}$ between samples in kittiwakes. In Hornsund (April/May 1985) kittiwakes caught polar cod significantly larger than both Brünnich's and black 

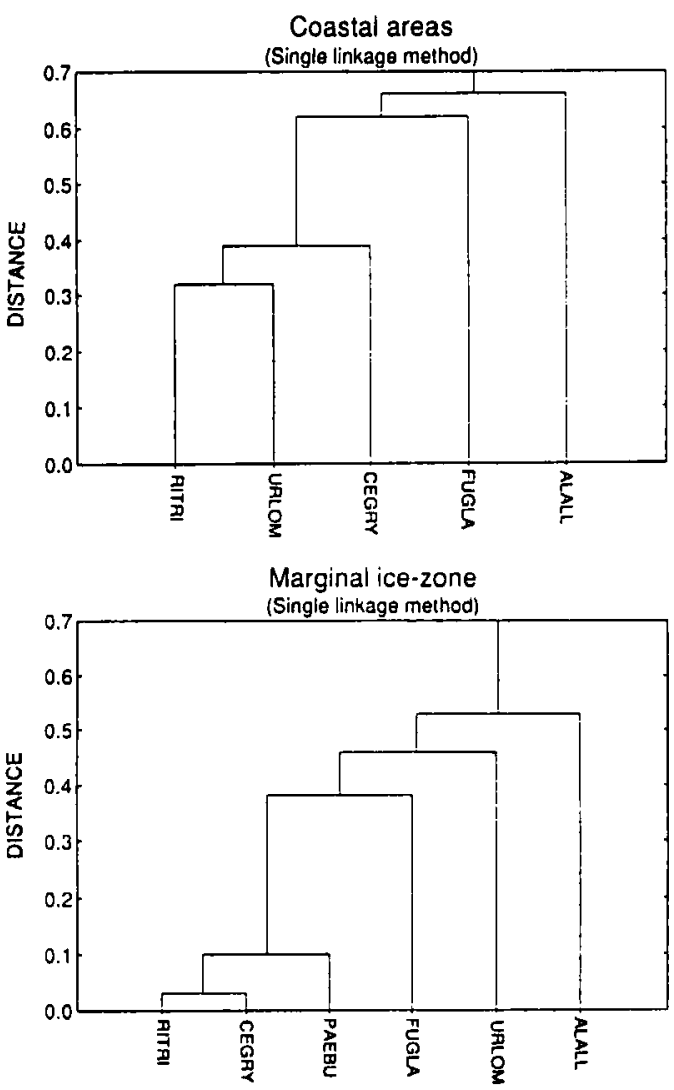

Fig. 8. Cluster diagram of dissimilarity in diet between five scabird species in coastal areas and six species in the marginal ice zone. The dissimilarity is measured as one minus Morisita's index, using the frequency of occurrence data.

guillemots $(t=11.3, p<0.001 ;$ and $t=6.1$, $\mathrm{p}<0.001$, respectively).

In summer, mean lengths of polar cod in kittiwakes varied from 106 to $134 \mathrm{~mm}$ (three data sets), compared to from 97 to $136 \mathrm{~mm}$ in black guillemots (two data sets). The majority of the polar cod eaten by kittiwakes and black guillemots in summer 1984 were probably one-year-old fishes (mean lengths: $97 \mathrm{~mm}$ and $106 \mathrm{~mm}$, respectively). In the other samples, however, the proportion of older polar cod was higher (mean lengths: 118 to $136 \mathrm{~mm}$ ).

Length distributions of Parathemisto libellula in samples from different seabird species and seasons are shown in Fig. 10. In spring and summer Brünnich's guillemots preyed upon relatively large amphipods, with mean lengths from 25.0 to $31.5 \mathrm{~mm}$. Kittiwakes, little auks and fulmars seemed to have taken smaller-sized amphipods during the summer, though the small sample sizes for kittiwakes and fulmars makes things uncertain. In the little auk samples collected from Isfjorden in July 1990, the mean length of $P$. libellula was $11.5 \mathrm{~mm}$, while the mean length of the much more frequent prey $P$. abyssorum was $6.1 \mathrm{~mm}$. The only two measured $P$. libellula in kittiwakes from the spring samples were, like most specimens found in the Brünnich's guillemot, from the larger cohort.

The majority of the Thysanoessa inermis taken by Brünnich's guillemots and little auks in spring and kittiwakes in summer were two-year-old individuals based on Dalpadado's (1989) classification of age groups of this euphausiid (Fig. 10). In the coastal summer sample of little auks from Isfjorden 1990, the mean lengths was $6.1 \mathrm{~mm}$ (range: $5.0-15.0 \mathrm{~mm}$ ), which indicates that these birds preyed upon the 1990 year's production of Thysanoessa inermis.

\section{Discussion}

In this study, which is based on 719 food samples from six seabird species in the Svalbard region, we have demonstrated the diversity of prey taken by seabirds in the region and also documented the dominance of certain key prey species, such as polar cod and Parathemisto, which are consumed by most seabirds. We found the diet of the smallest species studied, the little auk, least similar to the diet of the other species. It fed mainly on copepods.

\section{Fishes}

The polar cod is a principal prey species for seabirds in pelagic, ice-covered waters in the eastern Svalbard region (Table 3), as has been described for seabirds in the Canadian High Arctic (Bradstreet \& Cross 1982). The year classes I and Il of this species associate with ice and may be found in crevices in the ice or between sandwiched iceflows (Lønne \& Gulliksen 1989). Older polar cod are confined to the open water masses. Thus, the year classes of young polar cod may be treated as part of the sympagic fauna. The distribution of young polar cod in the ice-covered areas around Svalbard is not known in detail. However, a spawning area of the western component of the Barents Sea population of polar cod has been 


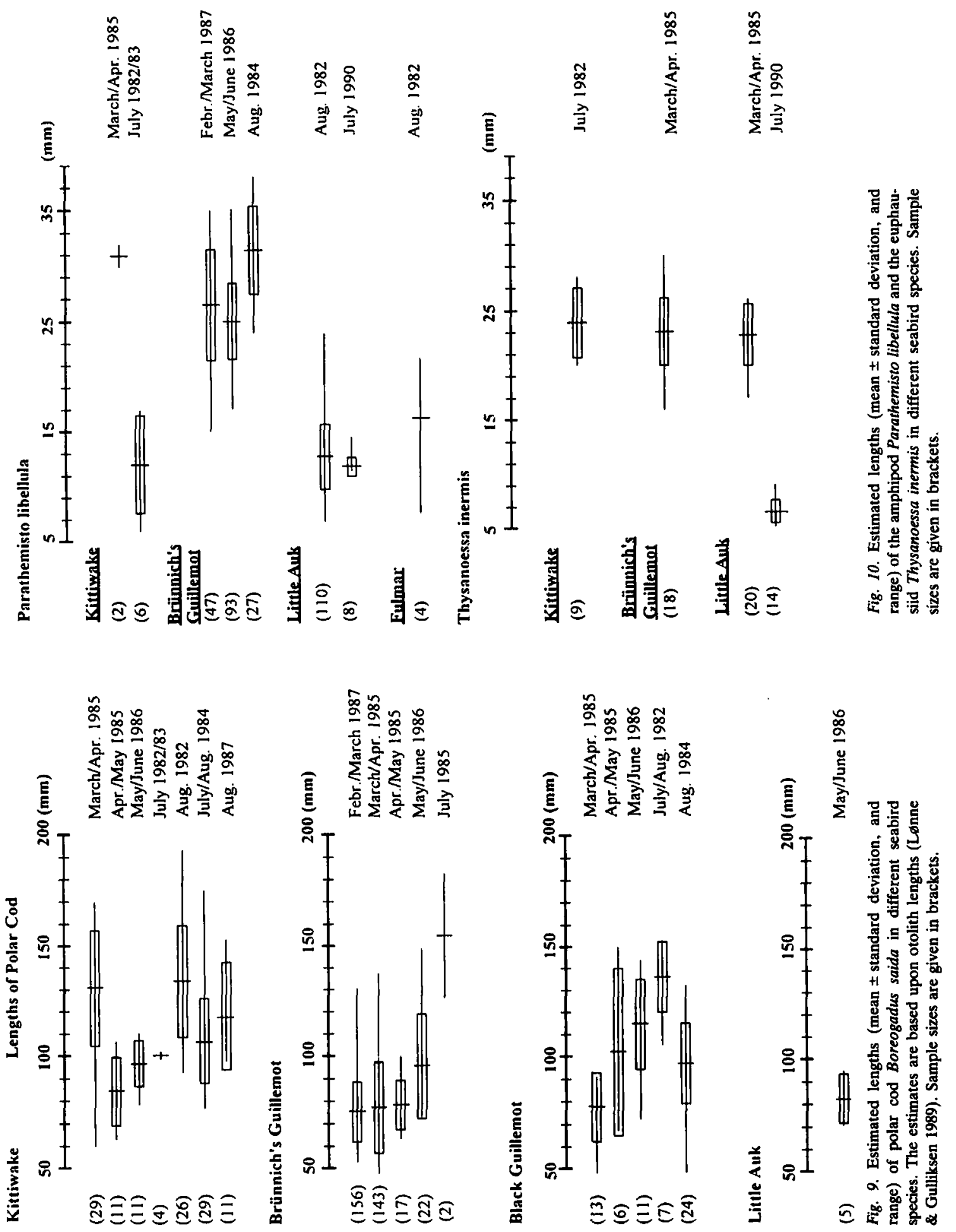


located east of Svalbard, in the region north of Hopen and east of Edgeøya (Loeng 1989). It is likely that the young polar cod from this locality will spread into large areas.

Capelin was not encountered frequently in the diet of any of the seabird samples, but was found in kittiwakes and Brünich's guillemots in low numbers. This pelagic fish is an important prey species for seabirds breeding at Bjørnøya (V. Bakken, pers. comm.) and Hopen $\left(76^{\circ} 30^{\prime} \mathrm{N}\right)(\mathrm{R}$. Barrett, pers. comm.). The Barents Sea capelin spawns along the coasts of North Norway and the Kola Peninsula, while the young capelin mature in the central or northern Barents Sea. Capelin is known to follow the retreating ice-edge northward during the summer, preying upon the growing populations of copepods (Loeng 1989). Capelin is normally not abundant in Svalbard waters except for the southeastern parts after the summer disappearance of sea ice. However, capelin may occasionally be found locally along the western coasts of Spitsbergen. The seabirds sampled for this study were collected outside regions where capelin is normally abundant at that time of year. Another factor that might contribute to the lack of capelin in the diet of the seabirds sampled is that the capelin stock in the Barents Sea was dramatically depleted in the 1980 s and the population crashed in 1985-86 (Hamre 1988).

\section{Pelagic crustaceans}

Our results indicate that Parathemisto libellula is also a key prey species for several species of seabirds in the Svalbard and northern Barents Sea areas, a finding similar to that for the Canadian Arctic (Bradstreet \& Cross 1982). This amphipod also comprises a significant proportion of the diets of ringed seals Pusa hispida (Gjertz \& Lydersen 1986) and harp seals Phoca groenlandica in Svalbard and the northern Barents Sea (Lydersen et al. 1991). According to our data, large sized cohorts, probably adults of $P$. libellula, form a staple food of Brünnich's guillemots in the marginal ice zone during spring. This prey must be very abundant in the marginal ice zone east of Svalbard. Large groups of Brünnich's guillemots, numbering thousands of birds, have been observed foraging in open leads in this area (personal obs.). Of the birds collected from these leads for dietary analysis, most were gorged with $P$. libellula. During summer a smaller cohort of
$P$. libellula, presumably the young of the year, becomes available to seabirds. $P$. libellula is not regarded as part of the sympagic fauna, but it may be found in the water column just below sea ice (Lønne \& Gulliksen 1991a). Wing (1976) studied the ecology of $P$. libellula and $P$. pacifica in southeastern Alaskan waters and found that both species migrate vertically between day and night most of the year. He suggested that $P$. libellula made an upward movement of $150-200 \mathrm{~m}$ each night with a significant part of the population between the surface and $50 \mathrm{~m}$. Similarly, Gulliksen (1984) reported that the biomass of this amphipod under land-fast ice in eastern Svalbard varied between day and night, with the highest biomass around midnight. This vertical migration may influence the availability of the amphipod as prey for seabirds, making them available in highest numbers for surface or near-surface feeders at night.

The smaller hyperiid $P$. abyssorum was found only in little auks taken along the western coast of Spitsbergen (Hornsund and Isfjorden). This amphipod was dominant in both areas during summer, though the specimens taken were much smaller than $P$. libellula. Zelichman \& Golovkin (1972) also found a high frequency of $P$. abyssorum in the diet of little auks at Novaja Zemlja. The $P$. libellula found in the summer samples of little auks were of the small cohort, probably the young of the year, similar in size to those found in little auks in Arctic Canada (Bradstreet 1982). Weslawski \& Kwasniewski (1983) suggested that P. abyssorum was an indicator of Atlantic Water in the Svalbard area, because in their study, the species was found only in Atlantic Water in the western parts and not in the Arctic Water in the eastern parts of the archipelago. However, the species is also widespread in the Arctic Ocean as well as in deep water in the sub-Arctic (Ekman 1953). In Lancaster Sound, Northwest Territories, $P$. abyssorum occurred in deeper water than $P$. libellula and were not thought to be important as prey for other seabirds with the possible exception of the deep-feeding Brünnich's guillemot (Bradstreet 1976).

Krill, mainly Thysanoessa inermis, were also important prey species in Brünnich's guillemot, but only in the spring. This is probably because these arcto-boreal euphausiids are primarily found in Atlantic Water masses, which around Svalbard are normally not ice-covered during summer (Dalpadado \& Skjoldal 1991). Birds were 
sampled only north of the frontal area between Atlantic and Arctic water masses during the summer.

Calanoid copepods were important as prey only for the little auk, although they also occurred infrequently in kittiwakes, Brünnich's and black guillemots. Three Calanus species are common in Svalbard waters: $C$. finmarchicus, confined to Atlantic Water masses, and $C$. glacialis and the larger $C$. hyperboreus in Arctic Water masses. One might expect the larger $C$. hyperboreus to be selected by little auks if equally accessible and abundant, because of the higher energy content per prey individual taken by the bird. In northwestern Baffin Bay, little auks selected the largest species of copepods ( $C$. hyperboreus) and the largest life stage of both $C$. hyperboreus and $C$. glacialis (Bradstreet 1982). However, in eastern Lancaster Sound, copepods were absent and the diet was dominated by amphipods (Bradstreet 1976). In our July samples from Isfjorden, $C$. glacialis (copepodite stage $V$ ) totally dominated in numbers, and only five specimens of $C$. hyperboreus were found. However, nothing is known about the composition of plankton available to little auks at the time of collection. Similarly, in ice-filled waters east of Svalbard in August 1982, the size distribution suggests that the $C$. finmarchicus/glacialis taken belonged to the largest stages (copepodite $\mathrm{V}$ and adults).

Decapod larvae were also frequent as prey for little auks in the coastal samples. The predominating species encountered was Eupagurus pubescens, which is abundant as zoea larvae in coastal Spitsbergen from April to September (Weslawski 1987).

\section{Polychaetes, squid and other soft-bodies prey}

Nereids (the only species identified was Nereis irrorata) were found in seabirds sampled both in coastal and ice-filled areas. Only the chitinous jaws were present, which have low digestibility and thus may remain in the digestive tract for long time. In the coastal samples, nereids are probably taken by black guillemots while feeding on benthic dwelling prey. Nereids were also recorded as prey for surface feeding seabirds such as kittiwakes and fulmars. These polychaetes are known to "swarm" in surface waters during reproduction and may thus be available to surface feeding seabirds (Pettibone 1954).
The only remains of cephalopods found in the birds were their beaks. All beaks identified were from the squid Gonatus fabricii, a widely distributed species. Cephalopods were the dominant prey in coastal samples of fulmars, but only occurred at low levels in pelagic samples. Squid were also found in kittiwakes and Brünnich's guillemots, but only in coastal samples and in low numbers. The distribution and ecology of $G$. fabricii in Svalbard is unknown, and its apparent difference in abundance in our samples from seabirds from coastal areas and the marginal ice zone cannot be explained. However, the presence of beaks in the stomach of fulmars agree with previous studies in Arctic regions (Duffy \& Sergant 1950; Belopolskii 1957; de Korte 1972; Bradstreet 1976; Lydersen et al. 1989). G. fabricii is found throughout the water column, with mainly small individuals occurring near the surface (Nesis 1965). The mean length of $G$. fabricii eaten by fulmars in Lancaster Sound was $143 \mathrm{~mm}(60 \mathrm{~g})$, which corresponds to an estimated age of 12 months (Bradstreet 1976).

No soft parts of nereids and squid were found in the samples. Thus, the importance of these taxa as prey for seabirds might be less than indicated by the frequency of occurrence and numerical abundance measures. Other soft-bodied prey that disappear rapidly from the digestive tract of the seabirds would be difficult to identify if not examined immediately after ingestion. We did not encounter organisms such as pteropods, ctenophores and scyphozoan jellyfish in our samples, but we suspect that they are taken by seabirds in the Svalbard region equally as much as by seabirds in other regions (Harrison 1984). We have observed fulmars feeding on jellyfish in western Spitsbergen coastal waters (F. Mehlum, pers. obs.).

\section{The importance of ice-associated prey}

The marginal ice zone in the waters around Svalbard comprises important habitats for several seabird species (Mehlum 1989). Certain species, such as the ivory gull, Ross' gull Rhodostethia rosea and black guillemot, are mainly associated with the sea ice in pelagic areas, while others, such as the little auk, Brünnich's guillemot, kittiwake, and fulmar, are distributed both in the marginal ice zone and in ice-free regions (Mehlum 1989). During the summer season a large proportion of 
the birds feeding in these areas are presumably non-breeding individuals (Mehlum 1989).

In the marginal ice zone seabirds forage deep in the water column as well as on sympagic organisms associated with sea ice. The sympagic fauna available as prey for seabirds have been classified into two types (Melnikov \& Kulikov 1980): (1) autochthonous ice-fauna associated with multiyear ice and including gammarid amphipods such as Gammarus wilkitzkii, Apherusa glacialis and Onisimus sp.; and (2) allochthonous ice-fauna, found only temporarily in the ice, which in the Barents Sea includes polar cod and is associated both with first-year ice and multi-year ice.

In Svalbard, sympagic amphipods were not the main food source for any of the six seabird species studied. These amphipods were most frequent in the little auk and the black guillemot, but they occurred only in 16.7 and $9.5 \%$ of the birds examined, respectively. In little auks, the percentage by weight of the different prey taxa in the summer samples showed that the sympagic amphipods $A$. glacialis and $G$. wilkitzkii accounted for as much as $78.9 \%$ of the total weight. However, this high abundance by weight was biased by the fact that all the 297 specimens were found in 6 of 21 birds (all 6 from the summer 1982 sample). It therefore seems that sympagic amphipods (the autochthonous ice-fauna) contribute little to the diet of seabirds foraging in ice-covered waters in the eastern Svalbard region.

According to Lønne and Gulliksen (1991a), the abundance of the sympagic fauna depends on the age and the structure of the subsurface of the ice. They found high densities of sympagic amphipods under multi-year ice, while there were few or none under first-year ice. The proportion of multiyear ice in the Barents Sea varies from year to year but is generally small in comparison with the waters north of Svalbard and in the Fram Strait in the northern part of the Greenland Sea. Based on Vinje's (1985) estimates, the maximum outflow of multi-year ice from the Polar Basin to the Barents Sea is $30,000 \mathrm{~km}^{2}$, or about $15 \%$ of the marginal ice zone at its maximum extent.

The relatively low proportion of multi-year ice in the Barents Sea compared to the waters north of Svalbard suggests a higher abundance of sympagic organisms north of Svalbard than in our sampling areas in the northern Barents Sea. This agrees with the results of Lønne \& Gulliksen (1991a, b). In multi-year ice north of Svalbard, Lønne \& Gabrielsen (1992) found that sympagic amphipods were more important as prey for little auks and Brünnich's guillemots than in first-year ice in the northern Barents Sea.

In the coastal areas and fjords in western Spitsbergen there is usually no sea ice during the summer months, and thus the sympagic fauna is not a potential food source for seabirds foraging in these areas.

Even though the sympagic fauna of amphipods may not be very important as prey for most seabirds in ice-covered waters near Svalbard, they may be indirectly important as part of the prey of polar cod, at least in multi-year ice (Lønne \& Gulliksen 1989). However, the diet of polar cod was dominated by calanoid copepods and Parathemisto in their study. Bradstreet \& Cross (1982) reported similarly that the diet of polar cod caught at the landfast ice-edge at offshore locations in Arctic Canada was dominated by copepods and Parathemisto, with only a small proportion of sympagic organisms present.

The occurrence of sympagic amphipods in the diet of little auks during late summer agrees with Bradstreet (1982) for northwestern Baffin Bay. Bradstreet (1982) also described a seasonal shift in prey taken by little auks, where calanoid copepods dominated the May samples and Parathemisto, Apherusa glacialis and polar cod dominated in the August samples. It is apparent from our data and from Lydersen et al. (1989) that a similar seasonal shift in diet occurs in the Svalbard region from summer to autumn. Copepods, which dominated the diet in our spring and summer samples, were absent in little auks collected by Lydersen et al. (1989) in SeptemberOctober in the Hornsund region of Svalbard; Parathemisto and polar cod and striped snailfish Liparis liparis dominated instead. The seasonal change in diet may be due to differences in availability of prey.

\section{Diet similarities among species}

When comparing the diets of the different seabird species, we found the greatest similarity in the diets of black guillemots and kittiwakes foraging in ice-filled waters. Both feed on ice-associated prey, primarily polar cod. In contrast, their prey are quite different in coastal areas, where the black guillemot takes mainly suprabenthic prey. At Hornsund, Lydersen et al. (1989) found the highest similarity in the autumn diets of the little auk and Brünnich's guillemot, both which feed 
mainly on polar cod and Parathemisto. The three pursuit-diving species studied (i.e. the three acids) differ considerably in size and feeding ecology. The Brünnich's guillemot feeds on medium and large sized pelagic prey, whereas the little auk takes small pelagic prey, and the black guillemot suprabentic prey (mainly fish and crustaceans) in inshore regions and ice-associated prey in the marginal ice zone. In all the three surface feeding seabird species, fish, especially polar cod, are an important part of the diet. In the ice-covered areas these seabird species probably take advantage of the high abundance of polar cod associated with sea ice. Kittiwakes in Hornsund (spring 1985) consumed significantly larger polar cod than both Brünnich's and black guillemots sampled during the same period. We have no good explanation for this difference, but the kittiwakes might have foraged in separate areas with a higher proportion of cod aged two-year-old or more.

\section{Foraging areas of birds collected in coastal regions}

During the breeding season, seabirds are constrained in their foraging range by distance to the breeding site. During the chick-rearing period, the young have to be fed at certain rates in order to maintain normal growth before fledging. We have no detailed information of the feeding locations used most frequently by seabirds in Svalbard and their relationship to where we collected birds in coastal areas. In southeast Svalbard, we have recorded Brünnich's guillemots flying northward with fish in their beaks as far as $95 \mathrm{~km}$ southeast of the nearest breeding colony ( $F$. Mehlum unpubl.). We have also observed large numbers of seabirds feeding in coastal areas in Kongsfjorden and Hornsund, indicating that at least some prey are taken close to the colonies. The black guillemot, unlike other seabirds studied, feeds only in coastal areas close to the breeding site, usually less than $1 \mathrm{~km}$ distant (Cairns 1987). In contrast to other Atlantic alcids, their foraging range is constrained by the high workload needed to feed their two-chick clutches which they rear all the way to fledging (Mehlum et al. 1993).

Some arctic seabird species are attracted to special features along the coast where food is abundant. These include glacier faces and river outlets where prey organisms, especially crustaceans, are concentrated and easily obtainable. The existence of such feeding areas in front of glaciers in Svalbard was observed at Nordenskiöldbreen in Billefjorden and Mittag-Lefflerbreen in Wijdefjorden by Hartley \& Fisher (1936). In their study, the two dominant seabird species foraging in the fjords along the glacier fronts were fulmar and kittiwake, which mainly preyed upon the euphausiid Thysanoessa inermis. Similar observations have been made elsewhere in Svalbard. Norderhaug et al. (1977) described the phenomenon at Smeerenburgbreen and Monacobreen in northwest Spitsbergen, while Mehlum (1984) reported concentrations of seabirds along the front of the large glacier Austfonna on Nordaustlandet, as well as along Kongsvegen and the outlets of several small rivers in Kongsfjorden. The literature also contains similar reports from Greenland (Hartley \& Dunbar 1938) and the Canadian Arctic (McLaren \& Renaud 1982; Renaud \& McLaren 1982). The exact nature of the mechanism responsible for the concentration of prey organisms in such areas is not known. Mehlum (1984) suggests that the aggregation of organisms is caused by passive upwelling in connection with fresh water outlets beneath the glacier or at river outlets. The outflow of fresh water generates a reaction current of salt water (below the fresh water) towards the glacier face or river outlet, and the organisms are transported upwards to the freshwater layer. When they experience lower salinity, they may be more or less immobilized and thus easy prey for the birds. In 1983, Mehlum (1984) observed large numbers of kittiwakes at river outlets in Kongsfjorden feeding upon the amphipod Parathemisto libellula. Numbers of amphipods were found dead, apparently dying by the low salinity. Aarset \& Aunaas (1987) have shown that this species is relatively intolerant to low salinity water. The flow of fresh water from arctic glaciers and rivers varies through the summer and is correlated to air temperature and precipitation (Repp 1979). The concentration of prey organisms most likely occurs only in periods with high fresh water outflow and may thus be an unreliable food source for the birds due to possible variations between years. For example, the concentrations found outside Nordenskiöldbreen in 1933 (Hartley \& Fisher 1936) were not found in the summers of 1921, 1926 and 1937 (F. C. Stott, pers. comm.). Similarly, seabird foraging activity at Austfonna was lower in 1982 than in 1981 (Mehlum 1984). Kittiwake concentrations at river outlets in Kongsfjorden were found in 1983 but not in 1984 
(Mehlum 1984). We suggest that prey concentrations at river outlets and glacier faces are utilised opportunistically by seabirds in years when these phenomena occur. The high proportion of Parathemisto and Thysanoessa found in our coastal samples of the surface feeding kittiwakes may be explained by such opportunistic foraging.

\section{Concluding remarks}

We would add that caution should be taken in the interpretation of our results dealing with the relative importance of different prey types in the diet of the six seabird species studied. In Table 2 we have for each seabird species pooled the data for all individuals sampled in coastal versus offshore, ice-covered regions (see Materials and Methods). Thus, differences in diet composition among samples sets in each of the two habitat types were not accounted for. Furthermore, sample sizes of the single data sets were different, which might bias the averaged frequency of occurrence presented in Table 2 . These problems were partly eliminated in Figs. 2-7, by splitting the data into spring and summer samples. Because of this potential bias we did not perform statistical tests for comparing the pooled data sets. Because of low sample sizes, we also were careful in our interpretation of differences in occurrence or numerical abundance between single data sets. Even though we were not fully able to demonstrate the variability in the seabirds' diet from one year to the other and despite the shortcomings of pooling sample sets, our extensive total material should give a reasonable general picture of the main prey types taken by the six seabirds species in the study areas and indicate differences among years and sampling localities.

An interesting follow up study would be to investigate the importance of capelin to seabirds foraging in the marginal ice zone in the northern Barents Sea in years when the stock of this key fish species in the Barents Sea ecosystem is abundant (Sakshaug \& Skjoldal 1989).

Acknowledgements. - We thank H. Dahlen, I. Gjertz, C. Lydersen, V. Ree, and E. Soglo for collecting seabirds, and I. Gjertz, Ø. Kaasa, J. Koszteyn, O. J. Lonne, and J. M. Weslawski for help with the analysis of stomach samples. We also want to thank M. Konarzewski and J. Taylor for providing the material of little auks from Hornsund 1987. R. Barrett, $I$. Gjertz, O. J. Lonne, G. L. Hunt, and two anonymous reviewers made valuable comments to the manuscript. The study was partly supported by the Norwegian Research Program for Marine Arctic Ecology (Pro Mare) of the Norwegian Research Council for Science and the Humanities.

\section{References}

Aarset A. V. \& Aunaas, T. 1987: Osmotic responses to hyposmotic stress in the amphipods Gammarus wilkitzkii, Onisimus glacialis and Parathemisto libellula from Arctic Waters. Polar Biol. 7, 189-193.

Belopolskii, L. O. 1957: Ecology of sea colony birds of the Barents Sea. [Transl. from Russian, 1961. Israel Prog. Sci. Tansl., Jerusalem.]

Bradstreet, M. S. W. 1976: Summer feeding ecology of seabirds in Eastern Lancaster Sound, 1976. LGL Limited, Environmental research associates, Toronto, Canada. $187 \mathrm{pp}$.

Bradstreet, M. S. W. 1980: Thick-billed murres and black guillemots in the Barrow Strait area, N.W.T., during spring: diets and food availability along ice edges. Can. J. Zool. 58, 2120-2140.

Bradstreet, M. S. W. 1982. Pelagic feeding ecology of Dovekies, Alle alle, in Lancaster Sound and Western Baffin Bay. Arctic 35, 126-140.

Bradstreet, M. S. W. \& Cross, W. E. 1982: Trophic relationships at High Arctic ice edges. Arctic 35, 1-12.

Cairns, D. K. 1987: The ecology and energetics of chick provisioning by black guillemots. Condor $89,627-635$.

Dalpadado, P. 1989: Some observations on moulting, growth and maturation of krill (Thysanoessa inermis) from the Barents Sea. J. Plankton Res. 11, 133-139.

Dalpadado, P. \& Skjoldal, H. R. 1991: Distribution and life history of krill from the Barents Sea. Polar Res. 10, 443-460.

de Korte, J. 1972: Birds, observed and collected by "De Nederlanse Spitsbergen Expeditie" in West and East Spitsbergen, 1967 and 1968-'69; first part. Beaufortia 19, 113-150.

Diamond, A. W. 1983: Feeding overlap in some tropical and temperate seabird communities. Studies in Avian Biology 8 , 24-46.

Duffy, D. C. \& Jackson, S. 1986: Diet studies of seabirds: a review of methods. Colon. Waterbirds 9, 1-17.

Duffy, E. \& Sergeant, D. E. 1950; Field notes on the birds of Bear Island. Ibis 92, 554-563.

Ekman, S. 1953: Zoogeography of the sea. Sidgwick and Jackson. London. 417 pp.

Franz, H. G. \& Diel, S. 1984: Secondary production of Calanus finmarchicus (Copepoda: Calanoidea) in a transitional system of the Fladen Ground Area (Northern North Sea) during the spring of 1983. XIX EMBS, Plymouth, Devon, K. 16-21 September 1984.

Frost, K. J. \& Lowry, L. F. 1981: Trophic importance of some marine gadids in northern Alaska and their body-otolith size relationships. Fish. Bull. U.S. 79, 187-192.

Gjertz, I. \& Lydersen, C. 1986. The ringed seal (Phoca hispida) spring diet in northwestern Spitsbergen, Svalbard. Polar Res. 4, 53-56.

Gjertz, I., Mehlum F. \& Gabrielsen G. W. 1985: Food sample analysis of seabirds collected during the 'Lance'-cruise in icefilled waters in Eastern Svalbard 1984. Norsk. Polarinst. Rapp. 23.

Gulliksen, B. 1984: Under-ice fauna from Svalbard waters. Sarsia 69, 17-23.

Hamre, J. 1988: Some aspects of the interrelation between the 
herring in the Norwegian Sea and the stocks of capelin and cod in the Barents Sea. International Council for the Exploration of the Sea. C.M. 1988/H:42, 1-15. (Mimeo).

Harrison, N. M. 1984: Predation on jellyfish and their associates by seabirds. Limnol. Oceanogr. 29, 1335-1337.

Hartley, C. H. \& Dunbar, M. J. 1938: On the hydrographic mechanisms of the so-called brown zones associated with tidal glaciers. J. Mar. Res. I, 305-311.

Hartley, C. H. and Fisher, J. 1936: The marine foods of birds in an inland fjord region in west Spitsbergen. Part 2. Birds. J. Animal. Ecol. 5, 370-389.

Horn. H. S. 1966: Measurement of "overlap" comparative ecological studies. Am. Nat. 100, 419-424.

Hunt, G. L. Jr. 1991: Marine birds and ice-influenced environments of polar oceans. J. Mar. Syst. 2, 233-240.

Ikeda, T. \& Skjoldal, H. R. 1989: Metabolism and elemental composition of zoo-plankton from the Barents Sea during early Arctic summer. Mar. Biol. 100, 173-183.

Loeng, H. 1989: Ecological features of the Barents Sea. Pp. 327-365 in Rey, L. \& Alexander, V. (eds.): Proc. 6th Conf. of the Comité Arctique Int; 13-15 May 1985. E. J. Brill. Leiden.

Lydersen, C., Angatyr, L. A., Wiig, Ø. \& Øritsland, T. 1991: Feeding habits of Northeast Atlantic harp seals (Phoca groenlandica) along the summer ice edge of the Barents Sea. Can. J. Fish. Aquat. Sci. 48, 2180-2183.

Lydersen, C., Gjertz, I. \& Weslawski, J. M. 1989: Stomach contents of autumn-feeding marine vertebrates from Hornsund, Svalbard. Polar Rec. 25, 107-114.

Lønne, O. J. \& Gabrielsen, G. W. 1992: Summer diet of seabirds feeding in sea-ice covered waters near Svalbard. Polar Biol. 12, 685-692.

Lonne, O. J. \& Gulliksen, B. 1989: Size, age and diet of polar cod, Boreogadus saida (Lepechin 1773), in ice covered waters. Polar Biol. 9, 187-191.

Lønne, O. J. \& Gulliksen, B. 1991a: On the distribution of sympagic macro-fauna in the seasonally ice covered Barents Sea. Polar Biol. $11,457-469$.

Lønne, O. J. \& Gulliksen, B. 1991b: Sympagic macro-fauna from multiyear sea-ice near Svalbard. Polar Biol. 11, 471477.

Løvenskiold, H. L. 1964: Avifauna svalbardensis. Norsk Polarinst. Skrifter $129.460 \mathrm{pp}$.

McLaren, P. \& Renaud, W. E. 1982: Seabird concentrations in late summer along the coasts of Devon and Ellesmere Islands, N.W.T. Arctic 35, 112-117.

Mehlum. F. 1984: Konsentrasjoner av sjøfugl langs kanten av isbreer og utenfor breelver på Svalbard. Fauna 37, 156-160.

Mehlum, F. 1989: Summer distribution of seabirds in northern Greenland and Barents Seas. Norsk Polarinst. Skrifter 191, $1-56$.

Mehlum F. 1990: Seabird distribution in the northern Barents Sea marginal ice-zone during late summer. Polar Res. 8, 6165.

Mehlum F. \& Bakken, V. (in press): Seabirds in Svalbard: status, recent changes and management. In Nettleship, D.
N., Burger, J. \& Gochfeld, M. (eds.): Seabirds on Islands: Threats, Case Studies \& Action Plans. International Council for Bird Preservation Techn. Publ. Cambridge, UK.

Mehlum F., Gabrielsen, G. W. \& Nagy, K. A. 1993: Energy expenditure by black guillemots (Cepphus grylle) during chick-rearing. Colon. Waterbirds 16 (in press).

Mehlum F. \& Gjertz I. 1984: Feeding ecology of seabirds in the Svalbard area - a preliminary report. Norsk. Polarinst. Rapp. 16.

Melnikov, I. A. \& Kulikov, A. S. 1980: The cryopelagic fauna of the central Arctic Basin. Biol Tsental'nogo Arkricheskogo Basseina. Pp. 97-111. Nauka, Moscow. (Canadian translation of Fisheries and Aquatic Sciences 4910).

Nesis, K. S. 1965: Distribution and feeding of young squids Gonatus fabricii (Licht.) in the Labrador Sea and the Norwegian Sea. Oceanology 5, 102-108.

Norderhaug, M., Brun, E. \& Møllen, G. U. 1977: Barentshavets sjøfuglressurser. Norsk Polarinst. Medd. 104, 1119.

Opalinski, K. W. \& Weslawski, J. M. 1989: Ecology, metabolic rate and metabolic adaptations in Spitsbergen amphipods. Pol. Arch. Hydrobiol. 36, 333-350.

Pettibone, M. H. 1954: Marine polychaete worms from Point Barrow, Alaska, with additional records from the north Atlantic and north Pacific. Proc. U.S. National Museum 103, 203-356.

Pielou, E. C. 1984: The Interpretation of Ecological Data. A Primer on Classification and Ordination. Wiley \& Sons, New York, $263 \mathrm{pp}$.

Renaud, W. E. \& McLaren, P. 1982: Ivory Gull (Pagophila eburnea) distribution in late summer and autumn in Eastern Lancaster Sound and Western Baffin Bay. Arctic 35, 141148.

Repp, K. 1979: Breerosjon, glacio-hydrologi og materialutslipp $i$ et høyarktisk miljø, Brøggerbreen, Vest-Spitsbergen. Upubl. Ph.D. Thesis, Univ. Oslo (in Norwegian).

Sakshaug, E. \& Skjoldal, H. R. 1989: Life at the Ice Edge. Ambio 18, 60-67.

Vinje, T. 1985: Drift, composition, morphology and distribution of the sea ice fields in the Barents Sea. Norsk. Polarinst. Skrifter 179 C. $26 \mathrm{pp}$.

Weslawski, J. M. 1987: Distribution of Decapoda (Crustacea) in South Spitsbergen coastal waters with remarks on their ecology and breeding biology. Polish Polar Res. 8, 121-134.

Weslawski, J. M. \& Kwasniewski 1983: Application of biological indicators to determine the reach and origin of sea currents within the region of Spitsbergen. Pol. Arch. Hydrobiol. 30, 189-197.

Wing, B. L. 1976: Ecology of Parathemisto libellula and $P$. pacifica (Amphipoda: Hyperiidea) in Alaskan Coastal Waters. Northwest Fisheries Center, Auke Bay Fisheries Laboratory, Processed Report March 1976. NOAA.

Zelickman, E. A. \& Golovkin, A. N. 1972: Composition, structure and productivity of neritic plankton communities near the bird colonies of the northern shores of Novaya Zemlya. Marine Biology 17, 265-274. 